\title{
PERAN PEREMPUAN MASA KINI PADA IKLAN TELEVISI (KAJIAN SEMIOTIKA ROLAND BARTHES)
}

\author{
Luly Zahrotul Lutfiyah ${ }^{1}$, Kingkin Puput Kinanti ${ }^{2}$ \\ IKIP Budi Utomo Malang, IKIP Budi Utomo Malang \\ ${ }^{1,2}$ Pendidikan Bahasa dan Sastra Indonesia, FPISH, Malang \\ e-mail: *1 zahrotullulyemail@gmail.com, ${ }^{2} \mathrm{t} @$ gmail.com
}

\begin{abstract}
Abstrak
Penelitian ini adalah penelitian mengenai peran perermpuan dalam iklan televisi yang dikaji dengan ilmu semiotika Roland Barthes. Peran perempuan dalam iklan televisi ini berebentuk tiga makna yaitu makna denotasi, makna konotasi dan mitos. Jenis penelitian adalah deskriptif kualitatif. Penelitian bertujuan untuk menemukan peran perempuan masa kini dalam iklan televisi. Data penelitian adalah data deskripsi faktual transkripsi data. Penelitian menggunakan tiga metode, yaitu metode pengumpulan data, analisis data, dan penyajian analisis data. Pengumpulan data menggunakan metode simak dan catat berkaitan dengan peran perempuan yang ada dalam iklan televisi. Analisis data menggunakan analisis kajian semiotika Roland Barthes, yaitu menganalisis makna denotasi, makna konotasi dan mitos yang terdapat dalam iklan. Metode penyajian hasil analisis data adalah metode informal yaitu menggunakan kata-kata yang mudah dipahami. Hasil penelitian menunjukkan bahwa peran perempuan dalam iklan sangatlah penting mulai dari perempuan yang berprofesi menjadi ibu rumah tangga yang berbisnis online sampai hubungan antara ibu dan anak.
\end{abstract}

Kata kunci: peran perempuan, iklan televisi, semiotik.

\section{A. PENDAHULUAN}

Peran perempuan masa kini di Indonesia dalam iklan televisi digambarkan sebagai perempuan yang serba bisa berbeda dengan iklan televisi di era dua ribuan ke belakang dimana peran wanita hanya sebagai pelengkap dan fokus hanya pada kecantikan paras dan keelokan tubuh perempuan dan status sosial perempuan Indonesia di bawah laki-laki. Dalam perkembangannya, karena moderanisasi dan emansipasi kemudian memposisikan perempuan sejajar dengan laki-laki dan mengubah paradigma bahwa perempuan dapat berkiprah seperti laki-laki.

Iklan televisi yang mengangkat tentang perempuan di lingkungan sosial mengakibatkan perempuan mengalami perubahan pergeseran peran gender. Salah 
satunya adalah peran perempuan sebagai ibu rumah tangga yang juga bekerja. Perempuan yang berperan sebagai wanita karir tetapi tetap mengedepankan perannya sebagai istri dan ibu bagi anak-anaknya. Perempuan pada masa lampau dianggap sebagai kaum pelengkap pria yang hanya berkutat di dalam rumah tapi pada masa kini perempuan sudah setara dengan pria.

Pola interaksi yang terjadi dalam iklan televisi yang kami dapatkan banyak mengangkat peran perempuan ke arah yang positif dimana dalam beberapa iklan yang diteliti oleh peneliti peran perempuan sebagai pemeran utama bukan lagi sebagai peran pendukung. Iklan di media televisi, perempuan menempati posisi sentral dalam iklan berbagai produk, baik produk kecantikan, produk makanan yang identik dengan peran perempuan sebagai ibu. Pertimbangan produsen menggunakan perempuan sebagai bintang atau model iklannya, karena daya tarik peran perempuan masa kini makin luar biasa.

Peran yang disandang perempuan menjadi berbagai peran contoh dalam iklan yang kami dapat perempuan berperan ganda ada yang berperan sebagai aktris dan juga sebagai pelajar berprestasi, ada yang menjadi ibu rumah tangga dan menjalankan bisnis online. Ada juga iklan yang menceritakan seorang anak perempuan remaja berhijab bercita-cita menjadi petinju. Berdasarkan paparan di atas, disusunlah rumusan masalah sebagai berikut. Bagaimana peran perempuan dalam media televisi ?

Berkaitan dengan rumusan masalah di atas, penelitian ini bertujuan, memaparkan, mengklasifikasikan dan menunjukkan bentuk peran perempuan dalam iklan televisi.

Penelitian ini penting untuk dilaksanakan karena beberapa hal, 1) terjadinya pergeseran peran perempuan masa kini dalam iklan televisi 2) Penelitian mengenai peran perempuan sangat penting sebagai upaya untuk mendata dan memberikan sumbangan bagi kajian ilmu semiotika sebagai fenomena kebahasaan yang berkembang dan bersifat dinamis.

\section{B. KAJIAN TEORI}

\section{Iklan Televisi}

George E. Belch dan Michael A. Belch. dalam Morrisan M.A. (2010:14) menyatakan iklan atau advertising mempunyai arti produk komersial yang ditayangkan di televisi dan sifatnya berbayar. Iklan televisi terdiri dari dua komponen yaitu video 
dan audio. Morissan (2010:365) menyatakan dua komponen tersebut harus bekerja sama untuk menciptakan efek dan sekaligus mampu menyampaikan pesan iklan kepada khalayak. Video fokus pada pengambilan gambar pada iklan sehingga akan berpengaruh pada produk yang akan didistribusikan ke khalayak. Sedangkan audio berperan sebagai pengisi suara ataupun musik pengiring pada suatu produk yang diiklankan khususnya di media televisi. Iklan dalam televisi bertujuan untuk mempersuasi masyarakat agar tertarik untuk membeli produk yang diiklankan.

Iklan dan media tidak bisa dipisahkan keberadaanya, iklan dapat mempengaruhi dan merubah pola pikir di tatanan kehidupan bermasyarakat, iklan juga bisa menjadi tolak ukur realita sosial (Berger, 2000:54-55).

Analisis semiotik dapat digunakan untuk menggambarkan program-program yang ada di televisi, dengan fokus pada narasi. Dalam pandangan semiotik (Sobur, 2001:87). media televisi erat kaitannya dengan keberadaan iklan dan beredarnya aneka jenis periklanan. Sifat dari iklan itu sendiri membujuk khalayak untuk mengkonsumsi atau menggunakan produk yang telah diciptakan oleh produsen iklan. Televisi adalah medium kompleks yang menggunakan bahasa verbal, bahasa gambar, dan suara untuk menghasilkan impresi dan ide-ide (Berger, 2000:32-34).

\section{Semiotika}

Semiotika adalah suatu ilmu atau metode analisis untuk mengkaji tanda dan makna (Sobur, 2006:15). kajian semiotika sendiri mengkaji tentang tanda bahasa yang beredar I masyarakat luas tanda (Hartoko dan Rahmanto, 1986:131). Kata "semiotika" itu sendiri berasal dari bahasa Yunani "semeion" yang berarti "tanda" (Sudjiman dan Van Zoest , 1996) atau "seme" yang berarti "penafsir tanda" (Cobley dan Jansz, 1999:4). Ferdinand de Saussure (1916. Pada penelitian ini menggunakan teori dari Roland Barthes yang dikenal dengan "order of signification" dimana dalam gagasan Barthes terdapat makna denotasi, makna konotasi dan mitos (Krisyantono, 2009:270).

\section{METODE PENELITIAN}

Penelitian ini merupakan penelitian Semiotika dengan fokus pada kajian peran perempuan. Jenis penelitian adalah deskriptif kualitatif. Penelitian deskriptif karena penelitian akan dijelaskan kata-kata. Objek penelitian adalah bahasa tulis dalam iklan 
televisi. Dalam melaksanakan penelitian, peneliti melakukan beberapa hal, mulai dari pengumpulan data, analisis data, dan penyajian analisis data.

Data dalam penelitian ini terdapat terdapat data tulis yaitu berupa teks iklan yang telah dideskripsikan secara faktual.Pengumpulan data tertulis dilakukan dengan cara mengambil data tertulis berupa iklan di media televisi. Data dikumpulan dengan metode simak diikuti dengan teknik simak bebas libat cakap (SBLC). Keseluruhan data tersebut disimak, dikumpulkan, dan diseleksi sesuai topik, yaitu peran perempuan. Selanjutnya data diklasifikasikan berdasarkan makna denotasi dan makna konotasi Roland Barthes.

Teknik analisis data yaitu model interaktif yaitu reduksi data, sajian data, dan penarikan kesimpulan. Penyajian analisis data dilakukan dengan bentuk narasi. Penyajian ke dalam bentuk narasi dibagi dua jenis, yaitu formal dan informal (Sudaryanto, 1993:145). Penyajian hasil analisis ini dilakukan secara informal karena penyajian analisis data dengan memakai kata-kata biasa yang mudah dimengerti dan dipahami.

Teknik analisis data merupakan cara peneliti menganalisis data yang sudah dikumpulkan, dianalisis menggunakan prosedur analisis data model intraktif (Mills dan Huberman dalam Sugiyono, 2015:337) penelitian secara berlangsung dan terus menerus dilakukan hingga tuntas, sehingga data yang dianalisis lengkap.

\section{HASIL DAN PEMBAHASAN}

\section{Iklan Bumbu Racik Indofood}

Narasi: Di saat Ibu mengemas paket untuk bisnis online, seorang laki-laki (suaminya) bertanya tentang lancar atau tidaknya bisnis online yang dijalani. Sang Ibu menjelaskan, jika bisnisnya laris dan sudah menerima lima puluh order yang sudah dipacking dan tinggal mengirim saja, sambil menujukkan paket yang sudah siap dan orderan yang ada di Handphonenya. Kemudian, suaminya bertanya mengenai masakan untuk keluarga. Ibu memastikan sudah, karena sudah ada trik cerdik untuk meracik waktu ditengah kesibukan. Sama halnya dengan bumbu racik Indofood yang telah menjadi andalan ibuibu untuk meracik makanan sempurna dengan waktu yang singkat. Suaminya mengatakan, bahwa masakan enak dan bisnisnya pun lancar. Trik meracik hidup ibu, ya Racik. 


\section{Komunikasi Verbal:}

Suami : "Bu, gimana bisnis onlinenya?"

Ibu : "Laris, udah terima 50 orderan. Udah dipacking, udah siap dikirim."

Suami : "Kalau masak untuk keluarga?"

Ibu : : "Udah dong, kan ada triknya."

Narator : :Selalu ada trik cerdik meracik waktu di tiap kesibukan. Sama seperti Racik yang jadi andalan ibu, memasak racikan sempurna dalam waktu singkat."

Suami : "Waah, masakan enak, bisnis lancar. Jadi, trik meracik hidup ibu?"

Ibu : "Ya Racik."

Narator : "Dari Indofood."
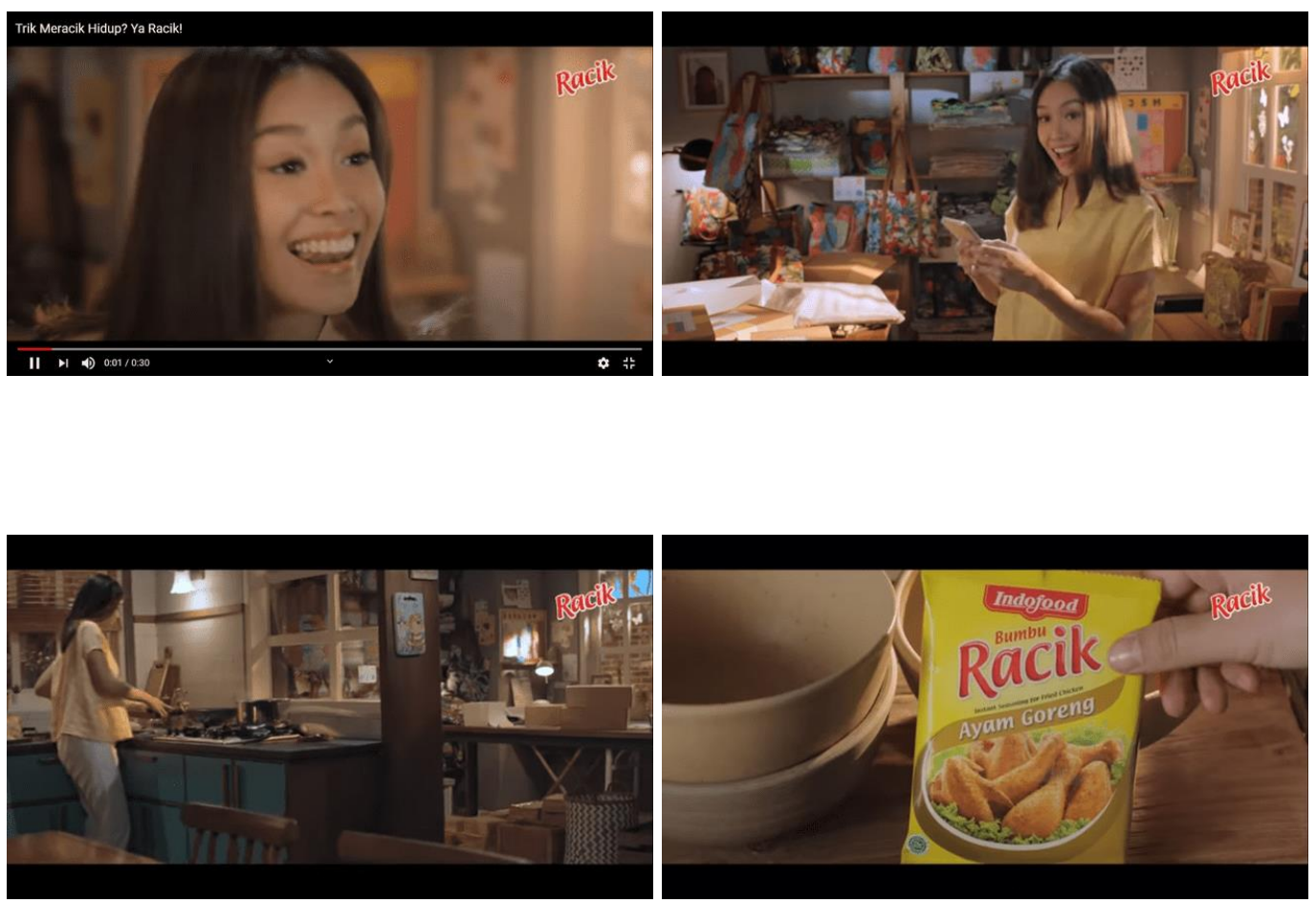

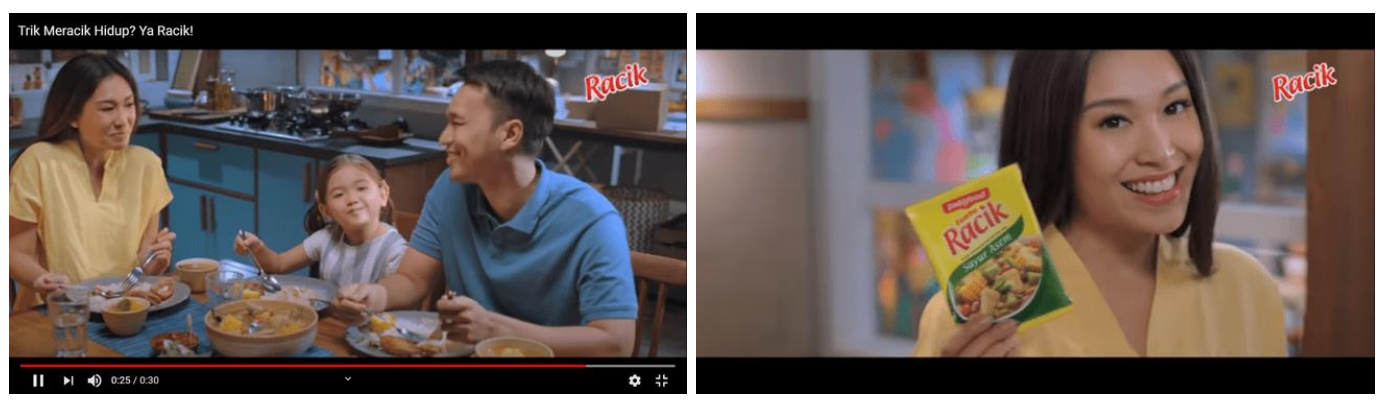

\section{Iklan Wardah - Selalu Bersyukur ft. Dewi Sandra}

Narasi: Perempuan berkerudung merah muda membuka jendela, menghirup oksigen pagi yang diproduksi oleh pepohonan sekitar rumah, selalu bersyukur masih dapat menghirup udara pagi yang segar. Setelah menggunakan make up Wardah yang terlihat cantik, perempuan berkerudung merah muda dan biru menaiki mobil. Hujan mengguyur bumi dengan deras, orang-orang menggunakan payung terlihat menyeberangi jalanan guna menuju tempat tujuan. Hujan adalah berkah yang diturunkan Tuhan untuk umatNya. Saat berjalan berdua, ada seorang anak laki-laki yang menabrak mereka dan menjatuhkan truk mainan. Kedua perempuan itu, perempuan berkerudung merah dan perempuan berkerudung biru, mengejar anak laki-laki berbaju kuning yang menabrak mereka tadi. Setelah berhasil mengejarnya, kedua perempuan itu memberikan truk mainan kepada anak laki-laki tersebut. Anak laki-laki tersebut menerimanya, kemudian menyentuh dagunya sebagai isyarat berterima kasih. Ternyata, tempat yang keduanya datangi adalah sebuah panti asuhan yang anak-anaknya memiliki kelainan tuna wicara. Melihat kedua perempuan tersebut, anak-anak panti asuhan berhamburan keluar dan memeluk mereka berdua. Kedua perempuan tersenyum bahagia. Adzan berkumandang. Semua anak panti, perempuan berkerudung merah muda, perempuan berkerudung biru dan ibu panti duduk di kursi meja makan dan berbuka bersama. Ketiga perempuan dewasa disana menuntun anak-anak untuk berdoa menggunakan bahasa isyarat. Iklan ditutup dengan adegan perempuan berkerudung merah muda dan perempuan berkerudung biru tengah berpelukan dan tersenyum, selalu bersyukur atas apapun yang mereka miliki.

\section{Komunikasi Verbal}

Narrator : "Alhamdulillah, masih bisa menghirup udara pagi ini. Bersyukur atas berkah yang diturunkan.”

Musik : "Bersyukur selalu." (dengan nada sebuah lagu) 
Narrator : "Bersyukur bisa merasakan kebahagiaan orang lain dan hangatnya kebersamaan."

Musik $\quad$ : (suara adzan)

Narrator : "Jalani ramadhan lebih bermakna dengan selalu bersyukur. Wardah, cantik dari hati."
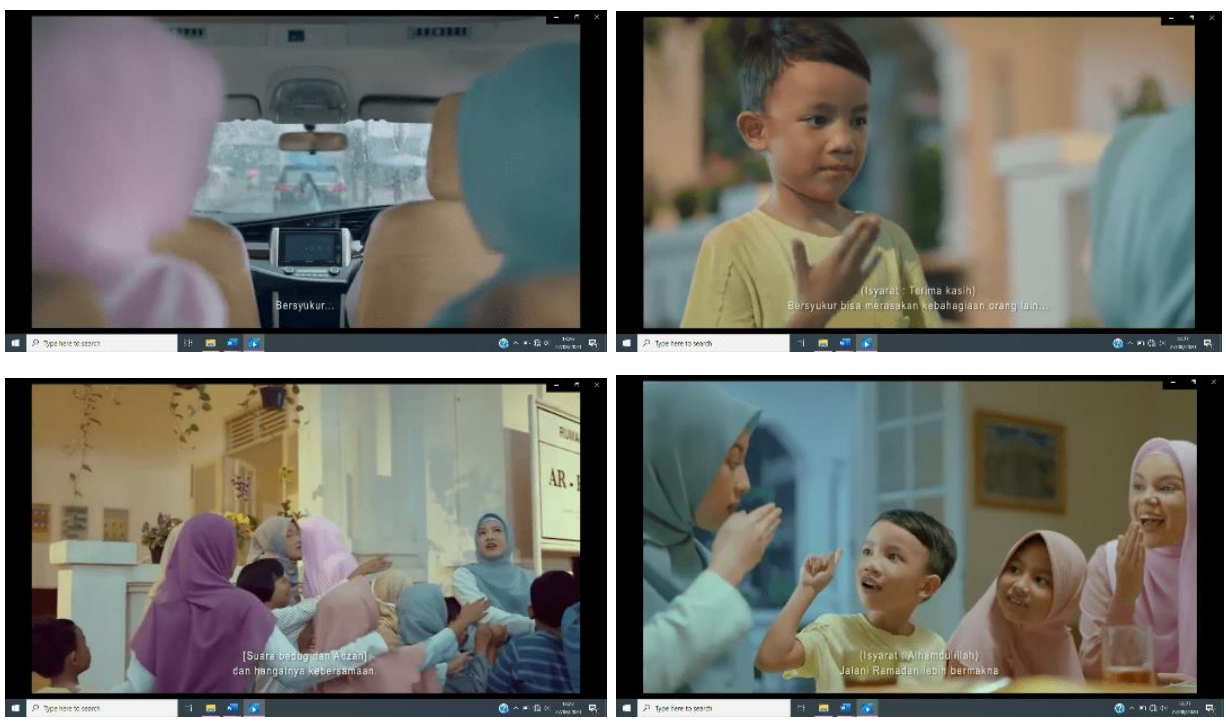

\section{Iklan Ponds White Beauty}

Narasi: Di dalam iklan tersebut, seorang anak menginginkan dirinya menjadi seorang petinju. Tapi, anak tersebut tidak yakin mamanya akan menyetujui. Saat anak tersebut pulang terlambat, mamanya menanyakan sebab dari keterlambatan tersebut. Dia memberikan alasan yang tidak sesuai dengan apa yang dia lakukan, dia mengatakan jika ada banyak buku baru di perpustakaan. Ketika membersihkan diri dengan mencuci muka menggunakan Ponds White Beauty, dia merasa bersalah karena sudah membohongi mamanya. Setelah mencuci muka, dia mengatakan yang sejujurnya kepada mamanya. Belum juga sang anak mengatakan sesuatu, mamanya menanyakan sebab dari memar di wajah anaknya. Dia menjawab, bahwa dia sedang melakukan latihan menjadi petinju. Akhirnya, sang mama mendukung keputusan anak menjadi seorang petinju dan akan selalu mendukungnya.

\section{Komunikasi Verbal:}

Anak : "Jadi petinju, adalah impianku. Tapi, aku gak yakin Mama setuju."

Mama : : "Kok pulangnya agak telat?" 
Anak : "Ada banyak buku-buku baru di perpustakaan."

"Aku harus jujur ke Mama."

"Ma.."

Mama : "Muka kamu kenapa?"

Anak : "Aku lagi latihan jadi petinju, Ma."

Mama : "Mama akan selalu dukung kamu."

Narator : "Bersihkan ragumu dan lihat hasilmu."
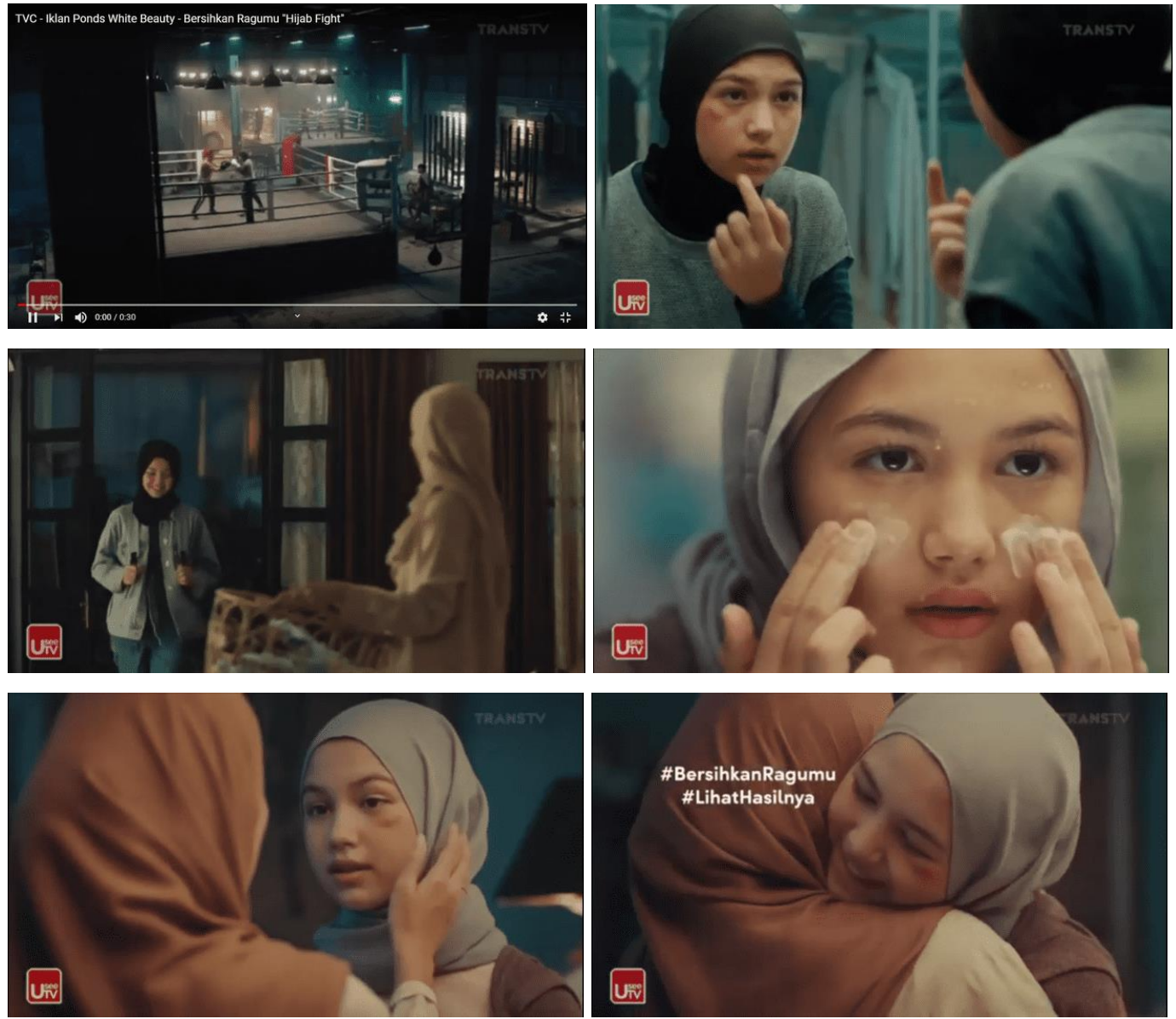

Sumber: www.youtube.com 
Tabel 1 Peran Perempuan dalam Iklan Racik, Wardah, dan Ponds

\begin{tabular}{|c|c|c|c|}
\hline IKLAN & MAKNA DENOTASI & MAKNA KONOTASI & MITOS \\
\hline RACIK 1 & $\begin{array}{l}\text { Seorang wanita yang } \\
\text { mengenakan baju berwarna } \\
\text { kuning, menggantungkan } \\
\text { tali meteran dilehernya } \\
\text { dengan ekspresi malu-malu } \\
\text { bersama dengan seorang } \\
\text { lelaki. }\end{array}$ & $\begin{array}{l}\text { Seorang istri yang bekerja } \\
\text { (penjahit) membuat } \\
\text { suaminya bangga. }\end{array}$ & $\begin{array}{l}\text { Wanita karir atau } \\
\text { wanita yang bisa } \\
\text { mencari uang sendiri } \\
\text { menjadi idaman } \\
\text { semua pria. }\end{array}$ \\
\hline RACIK 2 & $\begin{array}{l}\text { Seorang wanita yang } \\
\text { mengenakan baju berwarna } \\
\text { kuning tengah memegang } \\
\text { bunga dengan ekspresi } \\
\text { malu-malu bersama dengan } \\
\text { seorang lelaki yang sedang } \\
\text { memuji sambil memberinya } \\
\text { bunga }\end{array}$ & $\begin{array}{l}\text { Seorang istri yang pintar } \\
\text { mengurus rumah juga } \\
\text { membuat } \\
\text { suaminya. "Jago menata } \\
\text { hati" berarti pintar } \\
\text { mengatur urusan rumah } \\
\text { dan suami. }\end{array}$ & 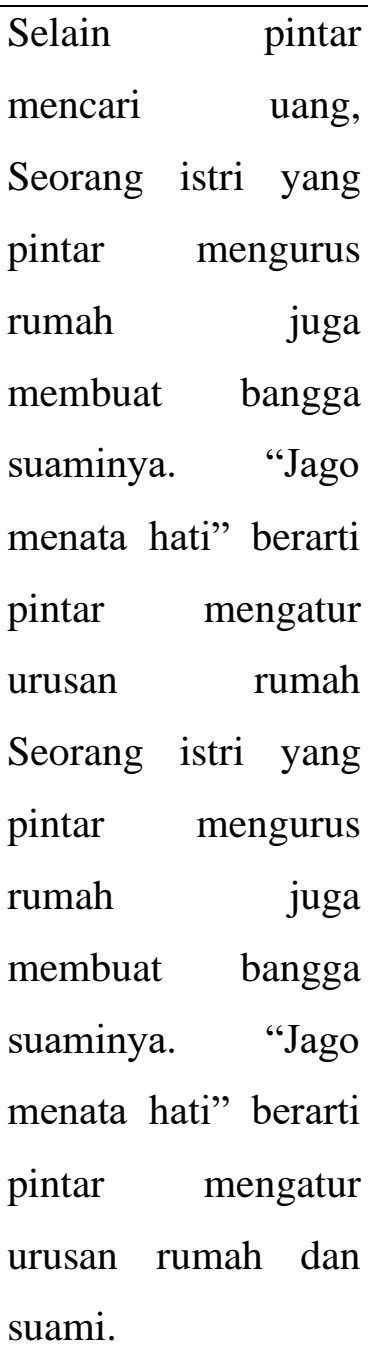 \\
\hline RACIK 3 & wanita yang & Lelaki juga menyukai & Kriteria lain wanita \\
\hline
\end{tabular}




\begin{tabular}{|c|c|c|c|}
\hline & $\begin{array}{l}\text { mengenakan baju berwarna } \\
\text { kuning tengah bersama } \\
\text { dengan seorang lelaki yang } \\
\text { memegang wajan dengan } \\
\text { latar tissue dan wastafel. }\end{array}$ & $\begin{array}{l}\text { wanita yang pintar } \\
\text { memasak. "Racik" disini } \\
\text { memiliki makna ambigu } \\
\text { yakni membuat bumbu } \\
\text { sendiri atau menggunakan } \\
\text { produk "racik" indofood. }\end{array}$ & $\begin{array}{ll}\text { idaman suami masa } \\
\text { kini adalah } & \text { wanita } \\
\text { yang } & \text { pintar } \\
\text { memasak. } & \end{array}$ \\
\hline RACIK 4 & $\begin{array}{l}\text { Seorang wanita yang } \\
\text { mengenakan baju berwarna } \\
\text { kuning sedang } \\
\text { membawakan makanan } \\
\text { sambil tersenyum untuk } \\
\text { lelaki yang sedang duduk. }\end{array}$ & $\begin{array}{l}\text { Dari aroma masakan } \\
\text { tercium aroma yang lezat. }\end{array}$ & Makanannya enak \\
\hline WARDAH 1 & $\begin{array}{l}\text { Perempuan berkerudung } \\
\text { merah muda membuka } \\
\text { jendela, menghirup oksigen } \\
\text { pagi yang diproduksi oleh } \\
\text { pepohonan sekitar rumah, } \\
\text { selalu bersyukur masih } \\
\text { dapat menghirup udara pagi } \\
\text { yang segar. Setelah } \\
\text { menggunakan make up } \\
\text { Wardah yang terlihat cantik }\end{array}$ & $\begin{array}{l}\text { Make up dan perempuan } \\
\text { suatu hal yang } \\
\text { berhubungan }\end{array}$ & $\begin{array}{l}\text { Make up menjadikan } \\
\text { perempuan terlihat } \\
\text { cantik }\end{array}$ \\
\hline Wardah 2 & $\begin{array}{l}\text { perempuan berkerudung } \\
\text { merah muda dan biru } \\
\text { menaiki mobil dan ditengah } \\
\text { jalan terjebak hujan,Hujan } \\
\text { mengguyur bumi dengan } \\
\text { deras, orang-orang } \\
\text { menggunakan payung } \\
\text { terlihat menyeberangi }\end{array}$ & $\begin{array}{l}\text { Hujan tidak menghalangi } \\
\text { aktifitas karena mereka di } \\
\text { dalam mobil dan } \\
\text { menjadikan mereka } \\
\text { bersyukur }\end{array}$ & $\begin{array}{l}\text { Standar ekonomi } \\
\text { diukur dengan alat } \\
\text { transportasi yang } \\
\text { digunakan }\end{array}$ \\
\hline
\end{tabular}




\begin{tabular}{|c|c|c|c|}
\hline & $\begin{array}{l}\text { jalanan guna menuju tempat } \\
\text { tujuan }\end{array}$ & & \\
\hline Wardah 3 & $\begin{array}{l}\text { Saat berjalan berdua, ada } \\
\text { seorang anak laki-laki yang } \\
\text { menabrak mereka dan } \\
\text { menjatuhkan truk mainan. } \\
\text { Kedua perempuan itu, } \\
\text { perempuan berkerudung } \\
\text { merah dan perempuan } \\
\text { berkerudung biru, mengejar } \\
\text { anak laki-laki berbaju } \\
\text { kuning yang menabrak } \\
\text { mereka tadi. Setelah } \\
\text { berhasil mengejarnya, kedua } \\
\text { perempuan itu memberikan } \\
\text { truk mainan kepada anak } \\
\text { laki-laki tersebut. Anak } \\
\text { laki-laki tersebut } \\
\text { menerimanya, kemudian } \\
\text { menyentuh dagunya sebagai } \\
\text { isyarat berterima kasih. } \\
\text { Ternyata, tempat yang } \\
\text { keduanya datangi adalah } \\
\text { sebuah panti asuhan yang } \\
\text { anak-anaknya memiliki } \\
\text { kelainan tuna wicara. }\end{array}$ & $\begin{array}{l}\text { Perempuan cantik tidak } \\
\text { hanya diukur dengan } \\
\text { kecantikan parasnya, } \\
\text { tetapi hati yang mulia } \\
\text { mencerminkan pribadi } \\
\text { yang baik dan menambah } \\
\text { nilai cantik itu sendiri }\end{array}$ & $\begin{array}{lr}\text { Kecantikan } & \\
\text { seseorang } & \text { tidak } \\
\text { hanya } & \text { parasnya } \\
\text { tetapi } & \text { juga } \\
\text { ditentukan } & \text { oleh } \\
\text { sikap } & \text { terhadap } \\
\text { sesama } & \end{array}$ \\
\hline Wardah 4 & $\begin{array}{l}\text { anak-anak panti asuhan } \\
\text { berhamburan keluar dan } \\
\text { memeluk mereka berdua. } \\
\text { Kedua } \\
\text { tersenyum bahagia. Adzan } \\
\text { berkumandang. Semua anak }\end{array}$ & $\begin{array}{l}\text { Kenikmatan puasa ketika } \\
\text { adzan berkumandang. } \\
\text { Kegembiraan anak-anak } \\
\text { terlihat ketika menyambut } \\
\text { buka puasa }\end{array}$ & $\begin{array}{llr}\text { Berbagi } & \text { di } & \text { panti } \\
\text { asuhan salah } & \text { satu } \\
\text { wujud cantik } & \text { dari } \\
\text { hati } & & \end{array}$ \\
\hline
\end{tabular}




\begin{tabular}{|c|c|c|c|}
\hline & $\begin{array}{l}\text { panti, perempuan } \\
\text { berkerudung merah muda, } \\
\text { perempuan berkerudung } \\
\text { biru dan ibu panti duduk di } \\
\text { kursi meja makan dan } \\
\text { berbuka bersama. }\end{array}$ & & \\
\hline Ponds 1 & $\begin{array}{l}\text { seorang anak menginginkan } \\
\text { dirinya menjadi seorang } \\
\text { petinju. Tapi, anak tersebut } \\
\text { tidak yakin mamanya akan } \\
\text { menyetujui. }\end{array}$ & $\begin{array}{l}\text { Petinju identik dengan } \\
\text { laki-laki, jarang sekali ada } \\
\text { petinju perempuan }\end{array}$ & $\begin{array}{l}\text { Olahraga tinju } \\
\text { identik dengan laki- } \\
\text { lakiponds }\end{array}$ \\
\hline Ponds 2 & $\begin{array}{l}\text { Saat anak tersebut pulang } \\
\text { terlambat, mamanya } \\
\text { menanyakan sebab dari } \\
\text { keterlambatan tersebut. Dia } \\
\text { memberikan alasan yang } \\
\text { tidak sesuai dengan apa } \\
\text { yang dia lakukan, dia } \\
\text { mengatakan jika ada banyak } \\
\text { buku baru di perpustakaan. }\end{array}$ & $\begin{array}{l}\text { Permasalahan hubungan } \\
\text { antara anak usia remaja } \\
\text { dan orang tua ketika } \\
\text { pulang terlambat } \\
\text { memberikan alasan yang } \\
\text { bisa diterima oleh orang } \\
\text { tua }\end{array}$ & $\begin{array}{l}\text { Masa remaja masa } \\
\text { mencari jati diri dan } \\
\text { tak jarang } \\
\text { menemukan konflik } \\
\text { dengan orang tua }\end{array}$ \\
\hline Ponds 3 & $\begin{array}{l}\text { Ketika membersihkan diri } \\
\text { dengan mencuci muka } \\
\text { menggunakan Ponds White } \\
\text { Beauty, dia merasa bersalah } \\
\text { karena sudah membohongi } \\
\text { mamanya. }\end{array}$ & $\begin{array}{l}\text { Seorang anak perempuan } \\
\text { berusia sekitar tujuh belas } \\
\text { tahun merasa bersalah } \\
\text { telah membohongi ibunya }\end{array}$ & $\begin{array}{l}\text { Anak perempuan } \\
\text { remaja dekat dengan } \\
\text { ibunya }\end{array}$ \\
\hline Ponds 4 & $\begin{array}{l}\text { Setelah mencuci muka, anak } \\
\text { perempuan remaja berhijab } \\
\text { tersebut mengatakan yang } \\
\text { sejujurnya kepada } \\
\text { mamanya. }\end{array}$ & $\begin{array}{l}\text { Anak perempuan remaja } \\
\text { berkata jujur pada ibunya }\end{array}$ & $\begin{array}{l}\text { Berkata jujur pada } \\
\text { orangtua adalah } \\
\text { sikap yang terpuji }\end{array}$ \\
\hline Ponds 5 & Belum juga sang anak & Seorang & Ikatan batin seorang \\
\hline
\end{tabular}




\begin{tabular}{|c|c|c|c|}
\hline & $\begin{array}{l}\text { mengatakan sesuatu, } \\
\text { mamanya menanyakan } \\
\text { sebab dari memar di wajah } \\
\text { anaknya. }\end{array}$ & $\begin{array}{l}\text { mengkhawatirkan keadaan } \\
\text { anaknya dengan adanya } \\
\text { luka memar di wajah } \\
\text { anaknya membuat sang } \\
\text { ibu makin khawatir }\end{array}$ & $\begin{array}{ll}\text { ibu pada anak } \\
\text { perempuan yang } \\
\text { kuat }\end{array}$ \\
\hline Ponds 6 & $\begin{array}{l}\text { Anak perempuan remaja } \\
\text { berhijab tersebut menjawab, } \\
\text { bahwa dia sedang } \\
\text { melakukan latihan menjadi } \\
\text { petinju. }\end{array}$ & $\begin{array}{l}\text { Menjadi petinju } \\
\text { kebanyakan didominasi } \\
\text { kaum laki-laki jarang } \\
\text { sekali perempuan memilih } \\
\text { profesi menjadi petinju }\end{array}$ & $\begin{array}{l}\text { Ada perempuan } \\
\text { remaja berhijab yang } \\
\text { berminat menggeluti } \\
\text { olahraga tinju }\end{array}$ \\
\hline Ponds 7 & $\begin{array}{l}\text { sang mama mendukung } \\
\text { keputusan anak menjadi } \\
\text { seorang petinju dan akan } \\
\text { selalu mendukungnya. }\end{array}$ & $\begin{array}{l}\text { Ibu yang baik mendukung } \\
\text { pilihan anaknya }\end{array}$ & $\begin{array}{lr}\text { Hubungan anak dan } \\
\text { ibu akan harmonis } \\
\text { jika mereka saling } \\
\text { jujur } & \text { dan } \\
\text { mendukung } & \\
\text { keputusan } & \text { yang } \\
\text { dipilih } & \end{array}$ \\
\hline
\end{tabular}

Pada tabel di atas telah diklasifikasikan makna denotasi, makna konotasi dan mitos dari iklan Racik, Wardah dan Ponds kemudian dianalisa letak peran perempuan dalam iklan tersebut. Peran perempuan yang ada di ketiga iklan merambah ranah publik jika ditelusuri dari iklan sebelumnya yang menggambarkan peran perempuan hanya berkutat di ranah domestik. Iklan mempunyai pengaruh yang besar terhadap konstruksi sosial yang dipegang oleh masyarakat di lingkungan (Sumartono, 2002: 28)

Berdasarkan ketiga iklan tersebut peran perempuan sudah menduduki dua ranah yaitu ranah domestik dan ranah publik, sebagai contoh dalam iklan racik Di saat Ibu mengemas paket untuk bisnis online, seorang laki-laki (suaminya) bertanya tentang lancar atau tidaknya bisnis online yang dijalani. Sang Ibu menjelaskan, jika bisnisnya laris dan sudah menerima lima puluh order yang sudah dipacking dan tinggal mengirim saja, sambil menujukkan paket yang sudah siap dan orderan yang ada di Handphonenya. Kemudian, suaminya bertanya mengenai masakan untuk keluarga. Ibu memastikan 
sudah, karena sudah ada trik cerdik untuk meracik waktu ditengah kesibukan. Sama halnya dengan bumbu racik Indofood yang telah menjadi andalan ibu-ibu untuk meracik makanan sempurna dengan waktu yang singkat. Suaminya mengatakan, bahwa masakan enak dan bisnisnya pun lancar. Trik meracik hidup ibu, ya Racik. Peran tokoh ibu dalam iklan menunjukkan bahwa seorang perempuan yang menjalankan profesi sebagai pebisnis online juga bertugas memasak untuk keluarga yang sudah menjadi kewajiban sebagai ibu rumah tangga. Citra perempuan dalam iklan televisi belum bergeser sepenuhnya masih dominan di ranah domestik belum sepenuhnya merambah ke ranah publik setinggi apapun pendidikan perempuan (Noviani, 2002)

Narasi iklan wardah yang mempromosikan produk kecantikan sedikit berbeda dengan peran perempuan di iklan racik.pada iklan Warrdah dinarasikan Perempuan berkerudung merah muda membuka jendela, menghirup oksigen pagi yang diproduksi oleh pepohonan sekitar rumah, selalu bersyukur masih dapat menghirup udara pagi yang segar. Setelah menggunakan make up Wardah yang terlihat cantik, perempuan berkerudung merah muda dan biru menaiki mobil dan berjumpa dengan anak penyandang disabilitas sampai pada akhirnya mereka berbuka puasa di panti asuhan di akhir iklan diwacanakan bahwa hidup harus bersyukur pada iklan wardah mengulas peran perempuan sudah merambah ke ranah publik dengan kehadiran mereka berpartisipasi di panti asuhan. Iklan kecantikan yang mengalami pergeseran tentang peran perempuan terlihat dalam iklan ponds dimana sosok perempuan yang diperankan remajaputri berhijab yang bercita-cita sebagai petinju, dimana petinju merupakan olahraga yang mayoritas ditekuni oleh kaum laki-laki. Perempuan digambarkan sebagai sosok yang positif cantik lembut, teliti, pintar, dan juga mempunyai sisi negatif yang irasional dan emosional (Lin, 2008:71).

\section{E. KESIMPULAN}

Kesimpulan yang didapat dari penelitian ini adalah peran perempuan dalam iklan di televisi kini mengalami bayak pergeseran. Perempuan tidak lagi menjadi tokoh kelas dua di bawah laki-laki. Peran perempuan masa kini tidak hanya berkecimpung di ranah domestik tetapi kini perempuan telah mengambil peran di beberapa ranah yang setara dengan kaum laki-laki. Gambaran peran perempuan dalam iklan televisi di atas jelas berbeda dengan gambaran iklan di masa lampu yang menjadikan peempuan sebagi 
makhluk pelengkap yang sering diekspos kemolekan tubuh dan parasnya saja, sedangakan dalam iklan masa kini banyak menyampaikan peran perempuan yang tangguh terlihat dari beberapa data iklan di media televisi yang telah ditemukan oleh peneliti antara lain iklan bumbu racik yang membuat peran seorang perempuan yang berpofesi sebagai ibu rumah tangga dan melakonkan bisnis online tetapi tetap melaksanakan tugas utamanya menjadi ibu rumah tangga yang mempunyai kewajiban memasak untuk keluarga. Selanjutnya peran perempuan terlihat di iklan Ponds seorang perempuan remaja putri berhijab ingin menjadi petinju. Jika kita tarik kembali keiklan masa lalu produk kecantikan tidak pernah mengulas sisi lain dari perempuan yang mempunyai peran setara dengan laki-laki.

\section{F. SARAN}

Pada penelitian selanjutnya dapat dikaji peran perempuan bukan dari iklan televisi tetapi dari media-media sosial lain.

\section{DAFTAR PUSTAKA}

Berger, Arthur Asa. 2000. Media Analysis Techniques. Yogyakarta : Penerbit Universitas Atma Jaya.

Bungin, Burhan. 2007. Analisis Data Penelitian Kualitatif: Pemahaman Filosofis dan Mertodologis ke Arah Penguasaan Model Aplikasi. Jakarta: Raja Grafindio Persada.

Fakih, Mansoer. 2006. Analisis Gender dan Transformasi Sosial. Yogyakarta : Pustaka Pelajar. 15

Lin, Ma. 2008. The Representation of the Orient in Western Women Perfume Advertisiment: A Semiotic Analysis. Intercultural Communication Studies: Beijing Foreing Studies University.

M.A, Morrisan. (2010). Periklanan: Komunikasi Pasar Terpadu. Jakarta: Kencana Prenada Media Group

Mulyana, Deddy. 2004. Komunikasi Efektif: Suatu Pendekatan Lintas budaya. Bandung: 
Remaja Rosdakarya.

Noviani, Ratna. 2002. Jalan Tengah Memahami Iklan. Yogyakarta: Pustaka Pelajar.

Piliang, Yasraf Amir. 1998. "Masih Adakah 'Aura' Wanita di balik 'Euphoria' Media”, dalam Idi Subandi Ibrahim et.al., Wanita dan Media, konstruksi Ideologi Gender dalam Ruang Publik Orde Baru. Bandung: PT Remaja Rosdakarya.

Sobur, Alex. 2004. Analisis Teks Media: Suatu Pengantar untuk Analisis Wacana, Analisis Semiotik, dan Analisis Framing. Bandung: Remaja Rosdakarya.

Glosarium seks dan gender. Yogyakarta: Carasvati Books.

Sumartono. 2002. Terperangkap dalam Iklan, Meneropong Imbas Pesan Iklan Televisi. Bandung: Alvabeta. 